\title{
What can Heidegger's Being and Time Tell Today's Analytic Philosophy?
}

\author{
Michael Esfeld \\ University of Konstanz, Department of Philosophy \\ P.O. Box 5560 D24, D-78457 Konstanz, Germany \\ Michael.Esfeld@uni-konstanz.de \\ (published in Philosophical Explorations 4 (2001), pp. 46-62)
}

\begin{abstract}
Heidegger's Being and Time sets out a view of ourselves that shows in positive terms how a reification of ourselves as minded beings can be avoided. Heidegger thereby provides a view of ourselves that fits into one of the main strands of today's philosophy of mind: the intentional vocabulary in which we describe ourselves is indispensable and in principle irreducible to a naturalistic vocabulary. However, as far as ontology is concerned, there is no commitment to the position that being minded is something beyond the physical. In particular, this paper shows how Heidegger's claim that being minded is tied to being-in-the-world links up with (a) externalism and (b) a social theory of intentionality.
\end{abstract}

\section{Introduction}

Some twenty years ago, the answer to the question what Heidegger's Being and Time can tell analytic philosophy would have been obvious: it has nothing to tell to analytically minded philosophers. But analytic philosophy has changed meanwhile. In the course of broadening the subjects that are treated by analytic argument, philosophers that are trained in this tradition take up Heideggerian themes. The focus is on Being and Time. Two topics from the first division of that book seem to match with central themes in today's philosophy: (a) externalism and Heidegger's claim that Dasein (that is us insofar as we are minded) is beingin-the-world, and (b) a social theory of intentionality and Heidegger's claim that Dasein is tied to Being-with (Mitsein), that is, to other people.

For Heidegger, being-in-the-world includes both being at things in the world and being with other people. In the same way, externalism in today's analytic philosophy includes both the view that the content of our thoughts depends on the non-human environment and the view that the content of our thoughts depends on social interactions. However, in order to be concise, when I speak of being-in-the-world and externalism without further qualification, I mean only the non-human environment. When I refer to the social claim, I talk in terms of Being-with [47] and a social theory of intentionality. Furthermore, by a social theory of intentionality, I mean a social theory of conceptual intentionality; that is a theory of intentional states which have a conceptual content such as believing that something is the case or intending that something becomes the case. According to such a theory, being in such states is tied to certain social practices.

The commentary of Hubert Dreyfus (1991) had a lot of influence on the development that resulted in associating Heidegger with externalism and a social theory of intentionality. ${ }^{1}$ To mention two further prominent examples, Gregory McCulloch (1995) considers Heidegger as

1 But see Christensen (1997) and (1998) as well as Ortega (2000) against this reception of Heidegger. 
an ally in favour of externalism and against a Cartesian epistemology and philosophy of mind (pp. 140-149) (see also Lafont (1994), Chapter 4, and McManus (1999)). John Haugeland suggests in a paper of 1982 that Heidegger puts forward a social theory of meaning in the spirit of Wittgenstein's Philosophical Investigations as well as that contemporary pragmatism which focuses on normative, social practices (see also Haugeland (1989), Brandom (1983), and McDonough (1995)).

One aim of this paper is to examine Heidegger's arguments for (a) being-in-the-world qua externalism and (b) Being-with qua a social theory of intentionality. The result of this examination will be ambiguous: On the one hand, there is a matching of minds between Heidegger and today's analytic philosophy when it comes to themes such as externalism and a social theory of intentionality. On the other hand, taking into account the arguments for these themes in today's analytic philosophy, there are shortcomings in the way in which Heidegger seeks to establish his claims.

However, the point of the paper is to argue that such shortcomings are not the point at issue. What themes such as externalism or a social theory of intentionality - and the analytic arguments for them - lack is a framework for an overall conception of ourselves as minded beings. My suggestion is that Heidegger's existentialism in Being and Time can supply such an overall framework. Thus, what we can get from Heidegger is a framework for a view of ourselves into which themes such as externalism and a social theory of intentionality - and the analytic arguments for them - then fit.

I first give a sketch of Heidegger's project in the first division of Being and Time (section 2). I relate this project to some recent developments in analytic philosophy (section 3) and give a brief systematic reconstruction of Heidegger's philosophy of mind (section 4). I then consider (a) Heidegger's arguments for being-in-the-world and their relation to externalism (section 5) and (b) his arguments for Being-with in connection with a social theory of intentionality (section 6). Finally, I suggest some brief conclusions (section 7).

\section{Heidegger's project in the first division of Being and Time}

Being and Time is conceived as a treatise on ontology. ${ }^{2}$ Heidegger sets out to examine what being is. His approach is to start with the being of those entities who are [48] able to ask the question what being is, namely ourselves $(\S 2$, p. 7$) .{ }^{3}$ The analysis of ourselves, insofar as we are able to ask what being is, is to result in a fundamental ontology $(\S 3$, p. $11 ; \S 4$, p. 13 ; $\S$ 28, p. 131; $\S 83$, pp. 436-437). Being and Time thus offers a theory of ourselves as minded beings.

When Being and Time is considered for systematic reasons in today's analytic philosophy, the point that it is intended as a treatise on ontology is neglected. When it comes to systematic philosophy in distinction to philological exegesis, it is legitimate to further develop certain features in the work of a historical author while sidelining the broader framework in which these features stand according to the intention of the author - as long as one acknowledges ignoring that broader framework. Thus, for instance, one can develop a social theory of meaning on the basis of certain remarks that Wittgenstein makes in the Philosophical

\footnotetext{
2 As to a comprehensive discussion of Heidegger's philosophy of being see Philipse (1998).

3 The page numbers refer to the German edition. These page numbers are reprinted in the margins of the English translation Heidegger (1962). All the German quotations are from the latest German edition (Heidegger (1993)), and all the English translations are adopted from the translation Heidegger (1962).
} 
Investigations; but in doing so one does not have to subscribe to the therapeutic attitude to philosophy that Wittgenstein demonstrates in his later work. In similar vein, we can receive Heidegger's analysis of Dasein without thereby being committed to regarding that analysis as resulting in a fundamental ontology. Hence, the aim of this paper is to take up one central aspect of Heidegger's intention in Being and Time - namely his project in the first division and to develop that project in such a way that it can be employed as an overall framework for today's philosophy of mind.

Furthermore, for lack of space, I shall not go into the link that Heidegger establishes between Dasein and time in the second division of Being and Time. That link is important when it comes to spelling out the details of Heidegger's view of Dasein. However, we get the main point by focussing on the first division: Dasein is concerned about its being, and it is being-in-the-world.

What is the idea that drives Heidegger's conception of ourselves insofar as we are minded beings? According to Heidegger, it is a cardinal mistake to try to understand ourselves in terms of the categories that apply to entities in the world, that is, categories of things with properties ( $\S 9$, pp. 42-45; $\S 83$, p. 437). Even if the entities in the world are not taken to be things, it is irrelevant to the point which Heidegger makes whether they are conceived as events or processes with properties, or space-time regions with properties, or states of affairs, or bundles of tropes, etc. Whatever the appropriate basic description of the entities that there are in the world may be, Heidegger's point is that we qua minded beings cannot be captured in the same way as those entities that make up the world. Heidegger's diagnosis of traditional philosophy is that it fails to develop an adequate theory of ourselves, because it reifies ourselves qua minded beings: we are considered either as some sort of an entity over and above the physical (dualism, in particular Descartes), or as being nothing but some physical stuff among other physical stuff (reductive physicalism) (§ 6, pp. 24-25; § 10, pp. 45-46).

Heidegger's central project in the first division of Being and Time is to set out in positive terms a view of ourselves qua minded beings that avoids a reification of the one or [49] the other sort. That explains why he seeks to develop an entirely new terminology. That explains furthermore why he brings in existentialism: there is no predetermined essence of ourselves qua minded beings, which can then be described by predicating properties of a thing. Instead, our essence is our existence $(\S 9$, p. 42). (The term "minded beings" looks of course like predicating a property of something - "Persons are minded beings" sounds like "Spheres are round beings". I use this term for lack of a more appropriate non-technical expression).

\section{Heidegger's project as a framework for contemporary philosophy}

One of the main strands in today's philosophy of mind can roughly be characterized as follows: the description of intentional states in intentional vocabulary cannot be reduced to a description in a vocabulary of the natural sciences. In other words, some sort of the familiar intentional vocabulary is indispensable in order to grasp ourselves as minded beings. This epistemological irreducibility notwithstanding, when it comes to ontology, there is no need to oppose the claim that, ontologically speaking, there is nothing over and above the physical: intentional states (a) may supervene on the physical, taken globally, and (b) they may be realized as physical states of a person in relation to an appropriate environment. There are many versions of this position, reaching from non-reductive physicalism - as defended by, for instance, Philip Pettit (1993) (Chapters 1 to 4) - to a radical externalism in the sense that not 
only meanings, but also the mind is not in the head (see McDowell (1994) in particular). This paper is not committed to any one particular version of this position. Its claim is that Heidegger's Being and Time has something to tell to all those analytic philosophers who favour some version of this position.

This position fits into the programme that I described in the preceding section, namely to avoid a reification of ourselves qua minded beings. The irreducibility of the intentional vocabulary in which we describe ourselves qua minded beings is to say that we are not just some physical stuff among other physical stuff. For this claim is not intended as a description of the current state of the art. Instead, it is a claim of a principled irreducibility that is independent of whatever progress the natural sciences may make in the future. However, on the other hand, the position under consideration refuses to move from epistemic irreducibility to any sort of an ontological dualism. In order to work this position out, we need (a) arguments that establish the described principled irreducibility and (b) an elaboration of what a view of ourselves that avoids a reification of the one or the other sort can look like in positive terms.

Externalism and a social theory of intentionality fit into this position, because they can be seen as providing arguments for a principled irreducibility. However, again, there are many versions of externalism and a social theory of intentionality. There are considerable differences among these versions. In particular, it is not mandatory to receive these topics as supplying arguments for a principled irreducibility. It is possible to pursue an externalism while having a naturalization of epistemology in mind (e.g. Dretske (1995)). Furthermore, it is possible to elaborate on a social theory of intentionality along the lines of sociobiology. Nonetheless, one of the driving forces in externalism is that if some sort of externalism is [50] true, then we have an argument to the effect that is in principle not possible to reduce the description of intentional states to a description of brain states. As the way in which John McDowell (1994) in particular conceives externalism makes clear, externalism can be developed into an argument for a principled irreducibility of the intentional vocabulary.

Turning to a social theory of intentionality, such a theory can be considered as making a case against the indeterminacy of meaning, insofar as claims about the indeterminacy of meaning are used as an argument in favour of eliminating the intentional vocabulary. Quine (1960) argues that given all the behaviourial evidence available, meaning is indeterminate. Kripke (1982), in his interpretation of Wittgenstein's Philosophical Investigations, can be seen as generalizing Quine's point by claiming the following: even if there were mental facts - such as entertaining mental ideas or grasping Fregean senses - these facts could not determine meaning either. As a solution to avoid an indeterminacy that would be fatal to meaning, Kripke suggests to focus on certain social practices, normatively described. The general claim is that insofar as meaning is determinate at all, it is determined by social practices. Insofar as these practices determine meaning, they can only be grasped by a description in normative, intentional vocabulary. Otherwise one would fall victim to the mentioned indeterminacies. The task then is to work out such a theory of social practices in detail. There is no space to go into that task here. Suffice it to mention that Brandom (1994) provides the most detailed account of such social practices as yet.

A social theory of intentionality and an externalism, pursued along the sketched lines, are pieces for a view of ourselves that contain a principled argument against a reduction or an elimination of the intentional vocabulary. Nonetheless, these pieces need a broader 
framework for an overall view of ourselves into which they can be embedded. One can maintain that there are examples of irreducibility to a basic physical theory even in the natural sciences. Descriptions in functional vocabulary arguably are such cases. If there is more to the irreducibility of the intentional vocabulary than what applies to functional descriptions in general, what is peculiar to the irreducibility of the intentional vocabulary? How can this irreducibility lead to a view of ourselves that avoids the pitfalls of reification? My claim is that externalism and a social theory of intentionality are in themselves not sufficient to answer these questions. Establishing this claim would, however, require a detailed examination of some versions of these positions.

All versions of externalism and a social theory of intentionality are directed against Cartesianism - both in epistemology and in ontology. ${ }^{4}$ Externalism is opposed to Cartesian epistemic self-sufficiency of intentional states as well as an ontological dualism of physical and mental substance. The same goes for a social theory of intentionality. However, the opposition to Cartesianism tells us only what the intended view of ourselves is not like. My suggestion is that Heidegger's conception of Dasein in Being and Time provides a framework that enables us to develop in positive terms a view of ourselves into which pieces such as the mentioned externalism and a social theory of intentionality fit. In order to gain from [51] Heidegger that framework, we have to focus on his existentialism. By Heidegger's existentialism, I mean his claim that our essence is our existence $(\S 9$, p. $42 ; \S 25$, p. 117 ; $\S$ 43 c, p. $212 ; \S 63$, p. 314). Heidegger describes ourselves qua minded beings as Dasein precisely because our essence is our existence $(\S 4$, p. $12 ; \S 9$, p. 42$) .^{5}$

\section{A brief systematic reconstruction of Heidegger's philosophy of mind}

Let us briefly reconstruct the outline of Heidegger's theory of ourselves qua minded beings step by step. The following steps are to sketch out a view of ourselves that explains why the intentional vocabulary is irreducible, although we are not some sort of an entity over and above the physical. The first step is the claim that our essence is our existence. This means that we do not have a predetermined essence or function, which can be described by predicating properties of a thing. Instead, we make ourselves insofar as we are minded beings. All our determinations as minded beings are self-determinations. However, we make ourselves not in the way in which we make, say, a table, namely by adding something to the furniture of the world (which then may or may not be reducible to an arrangement of particles, a state of a field, or whatever other basic physical entity). Thus, we make ourselves qua minded beings without thereby adding anything to what there is in the world. When Heidegger speaks about the way in which we make ourselves, he talks in terms of Dasein grasping its possibilities - "grasping" in a practical sense in the first place, which may then include a conceptualization of these possibilities as well. He goes as far as saying that Dasein

$4 \quad$ As to Heidegger's criticism of the Cartesian tradition, see Olafson (1987), Chapter 1.

5 Sartre (1976), in Being and Nothingness (English translation Sartre (1956)), takes up this point, but develops it in a way that is different from Heidegger's account. Heidegger objects to being called an existentialist in Sartre's sense in his Letter on Humanism (in Heidegger (1947), in particular pp. 72-73), which is a reaction to Sartre's popular exposition of his existentialism in Sartre (1996). However, the statements about Being and Time in the Letter on Humanism, written some twenty years later, can be taken to express a considerable shift of position. It may indeed be inappropriate to describe Heidegger's later philosophy as an existentialism. 
is its possibilities ( $§ 9$, pp. 42-43; § 31, pp. 143-144). He describes Dasein as projecting itself (Entwurf) ( $\$ 31$, p. 145). Thus, the idea is that all determination of something qua Dasein is self-determination by projection upon possibilities. We thereby bring about a determination of our existence ourselves instead of having a predetermined essence or function.

The claim that our sheer existence is our essence is hence to explain why we cannot be reified insofar as we are minded. Whether we can build a philosophy of mind on this claim depends on whether there is a plausible way that leads from this claim to the consciousness and intentionality that is characteristic of ourselves.

In grasping possibilities, Dasein brings itself into existence. This existence is such that each individual person is a token of Dasein. Heidegger speaks of Dasein being in each case mine (Jemeinigkeit) ( $\$ 9$, p. 42). In bringing itself into existence, a relationship to oneself is constitutive of each token of Dasein. Let us note this point as the second step. This relationship consists not only in bringing oneself into existence, but also in thereby being concerned about one's existence. According to [52] Heidegger, this concern includes three features: (a) It is some sort of an emotional state in the sense of a feeling of one's being. Heidegger talks in terms of Befindlichkeit ( $\$ 29)$. This feeling can be seen as the first manifestation of consciousness. (b) This feeling of one's being encompasses an understanding of one's being. This understanding is not a propositional affair in the first place. It is a practical understanding that is part of grasping one's possibilities in the mentioned practical sense ( $§ 28$, p. $133 ; \S 29$, p. $136 ; \S 31$, p. 142). In other words, the consciousness involved in feeling also is a sort of self-consciousness. (c) Most importantly, this relationship to oneself is acting for the sake of oneself in the sense of carrying out some of one's possibilities. Heidegger explains intentionality in terms of projecting oneself upon possibilities and realizing some of these possibilities. These possibilities have an intentional object other than the person herself, but are possibilities for one's own existence. Heidegger describes Dasein as "an entity which in each case is its possibilities, and is them in such a way that it understands itself in these possibilities and in terms of them, projecting itself upon them" ( $\S$ 39, p. 181; see also $§ 63$, p. 313).

In projecting itself upon possibilities, Dasein is ahead of itself $(\S 41, \mathrm{pp} .191-193 ; \S 46, \mathrm{p}$. 236). It is now evident why time in the sense of tense, that is, the distinction between past, present and future, is crucial for Dasein: in being ahead of itself, Dasein is orientated towards the future. Heidegger elaborates on this connection between Dasein and temporality in the second division of Being and Time. Before that, he sums up the first division in Chapter 6 by characterizing Dasein as care (Sorge) (in particular $\S 41)$. Care expresses what Dasein is, namely to shape one's existence by projecting oneself upon possibilities. Heidegger brings this conception to the point in his terminological use of "existence" according to which only Dasein has existence, because it alone has an understanding of its existence and cares about its existence ( $\$ 4$, p. $12 ; \S 9$, p. 42).

It would be inappropriate to describe the way in which Dasein brings itself into existence as a self-creation. ${ }^{6}$ For this is not a creation that adds anything to what there is in the world. Heidegger says that Dasein is thrown, because it does not bring about its own "there" $(D a):^{7}$

\footnotetext{
6 See also Sartre (1976), p. 22.

7 Compare Gethmann (1993), pp. 103-110.
} 
As being, Dasein is something that has been thrown; it has been brought into its "there", but not of its own accord. As being, it has taken the definite form of a potentiality-for-Being which has heard itself [which belongs to itself] ${ }^{8}$ and has devoted itself to itself, but not as itself. As existent, it never comes back behind its thrownness in such a way that it might first release this 'that-it-is-and-has-to-be' from its Being-its-Self and lead it into the "there". (§ 58, p. 284)

[53] This point is crucial in order to avoid a reification of Dasein. If Dasein created itself, Dasein would be something that is added to the furniture of the world. Precisely because Dasein cannot be reified, it does not create itself, but is tied to a world in which it is realized. Consequently, the possibilities for Dasein's existence are tied to a physical world. Their content - that is, what possibilities they are - derives from a physical world, and they are carried out in a physical world. By a physical world, or a world for short, I mean everything that is not a case of Dasein. We hence have an argument for Heidegger's famous claim that Dasein is being-in-the-world. Let us note this point as the third step: that the essence of Dasein is its existence in the sense that Dasein projects itself upon its possibilities implies that Dasein is being-in-the-world. Heidegger expresses the point that Dasein does not create itself by speaking in terms of Dasein being "thrown possibility through and through" ( $\$ 31$, p. 144; compare $\S 79$, p. 406).

We now gain a better understanding of what self-determination by projecting oneself upon possibilities means and what this does not mean: It does not mean that we ourselves create the content of these possibilities. That content results from the environment in which a person lives. Furthermore, since every determination of the existence of a person qua minded being is an act of self-determination, projecting oneself upon possibilities has a wider extension than conscious, deliberative choice among possibilities. The latter certainly is a case of selfdetermination; but the beliefs that are a prerequisite for considering different possibilities for action - and moreover all beliefs of whatever sort - are cases of self-determination too according to Heidegger's existentialism. Self-determination thus is some sort of a formal concept: it describes the structure of the relation to oneself that constitutes consciousness and intentionality without implying conscious, deliberative choice. That is why Heidegger talks in terms of thrown possibilities.

The reason why the intentional vocabulary is in principle not reducible to a physical vocabulary thus is this one: a relationship to oneself in the explained sense of selfdetermination cannot be produced by a chain of natural causes. Nonetheless, there may be necessary and sufficient physical - including physiological - conditions for there being entities that are characterized by such a relation to themselves. Therefore, the terms that are employed to describe this relationship to oneself cannot be captured in the vocabulary of the natural sciences. However, this relationship to oneself does not add anything to what there is in the world, since its content is not a matter of self-creation. The plausibility of this view hangs upon the question whether it is able to offer a better account of the relationship to

8 The German "gehört" admits of both interpretations. In contrast to the translation of Macquarrie and Robinson (Heidegger (1962)), it seems to me that what I have inserted in square brackets is what is intended in this passage. For, (1) "belong" makes much more sense in this context; and (2) if "heard" were meant, "gehört hat" would have been the more natural German expression. The German text reads: “... Seiend ist es als Seinkönnen bestimmt, das sich selbst gehört und doch nicht als es selbst sich zu eigen gegeben hat." 
oneself that characterizes a conscious, intentional being than the claim that this relationship is a case of natural causation. I cannot consider that question here.

The third step of being-in-the-world establishes an externalism on the ontological level in the first place. Dasein is not ontologically self-sufficient, but tied to a physical world. The argument for this claim does not proceed from the view that being minded is somehow realized as or identical with some physical stuff and therefore not ontologically self-sufficient. It rather starts from the idea that the essence of Dasein is its existence and that this existence cannot be reified. Thus, we get to this externalism on the basis of an analysis of what is constitutive of Dasein as such.

[54] Leaving aside Heidegger's intention to get from an analysis of Dasein to a fundamental ontology, we can integrate this conception of Dasein into the above mentioned position in today's philosophy in the following manner: If the way in which Dasein shapes its own existence does not add anything to the entities that there are in the world, then (a) nothing speaks against regarding the manner in which Dasein brings itself into existence by grasping its possibilities as supervening on the physical world taken globally; and (b) nothing hinders to consider Dasein's being-in-the-world in such a way that Dasein has some sort of a physical realization. This position, however, is not logically implied by the proposed view of Dasein.

According to Heidegger, Dasein is not only thrown into a world that is not Dasein, but also each token of Dasein is dependent on other tokens of Dasein with whom it exists. In Heidegger's terms, Dasein exists as Being-with (Mitsein). ${ }^{9}$ Being-in-the-world encompasses both being at things in the world and being with other people; both these features are equiprimordial (gleich ursprünglich) (Introduction to Chapter 4, p. 114; § 25, p. 116; § 39, p. 181 ; see also $\S 28$, p. 131). Let us note this point as the fourth step. Consequently, thrown into the world, the possibilities that Dasein has are not such that a token of Dasein in isolation can project itself upon possibilities for itself in isolation. Grasping possibilities is tied to interaction with others. It is here that the "they" (das man) comes into play. Only by first merging into the "they" can an individual token of Dasein then come to shape its own existence by realizing possibilities that it recognizes as possibilities for its own, individual existence; conscience (Gewissen) is crucial for that process of becoming an individual personality ( $\$ 54$, pp. 268-269).

Since intentionality in the first and foremost sense consists in Dasein shaping its being by projecting itself upon possibilities, there is a distinction between succeeding in shaping one's being and failing in that matter. Heidegger differentiates between authentic Being-one's-Self (eigentliches Dasein), that is, successful existence, and inauthentic Being-one's-Self (uneigentliches Dasein), that is, existence that is alienated from itself by remaining merged into the "they" all the time ( $\$ 9, \mathrm{pp} .42-43)$. The "they" into which Dasein merges in the first place is inauthentic Being-one's-Self. However, authentic Being-one's-Self does not lie beyond those social practices that constitute the "they". ${ }^{10}$ Heidegger makes clear that the characteristic features of Dasein are common to both authentic Being-one's-Self and

9 Dreyfus (1991) stresses this point in his commentary. See in particular Chapters 3 and 8.

10 See $\S 27$, p. 130; $\S 38$, p. 179; $\S 54$, p. 267. But compare John Haugeland's shift of position from Haugeland (1982) to the remarks in "Toward a New Existentialism" in Haugeland (1998), p. 4, and "The Intentionality All-Stars" in Haugeland (1998), p. 170, as well as the paper "Truth and Rule-Following", Chapter 13 in Haugeland (1998). 
inauthentic Being-one’s-Self ( $\$ 9$, pp. 43-44; compare $\S 25$, pp. 115-116; § 38, pp. 175-179). I shall therefore not further elaborate on this distinction.

The freedom of Dasein thus is limited in two ways: Dasein does not create itself. The possibilities upon which it projects itself are thrown possibilities; their content derives from the world. Furthermore, these possibilities are not such that each individual token of Dasein sets up its own possibilities. Dasein merges into the "they" in the first place. Owing to these limitations, there may be scope for a [55] position according to which the freedom of ourselves qua minded beings that is stressed by existentialism does not have to clash with causality in the physical world. However, there is no space to pursue this point here.

\section{Being-in-the-world and externalism}

In the last section, I have sketched out the main features of Heidegger's view of ourselves qua being minded as presented in the first division of Being and Time. Having the target in view to set out in positive terms a conception of ourselves that avoids a reification, we start with (1) the claim that our essence is simply our existence, which is to say that we make or determine ourselves insofar as we are minded beings by projecting ourselves upon possibilities. This implies (2) a relationship of each person to herself in the sense of caring about her existence. In order to avoid a reification, (3) making oneself qua minded being is not a self-creation, but takes place as thrown into the world. The possibilities for one's existence consequently are thrown possibilities whose content derives from a physical world and which require a physical world in which they are realized. Furthermore, (4) grasping these possibilities depends on social interactions. This is the framework for a view of ourselves that I suggested Heidegger's Being and Time can supply.

How shall we go on from here? My claim is this one: Against this background framework for a view of ourselves externalism and a social theory of intentionality now fit in as the manner in which we can further elaborate on this view of ourselves. I therefore propose to take a look at the connection between (a) being-in-the-world and externalism (in this section) and (b) Being-with and a social theory of intentionality (in the next section). As explained in the last section, being-in-the-world is an ontological externalism: insofar as we are minded beings, we are not ontologically self-sufficient. Consequently, insofar as something has intentional states and thus is a minded being, it is dependent on being embedded in a nonhuman environment. That dependence is not a mere causal dependence, and the claim of such a dependence is not a contingent thesis that applies only to worlds whose physical and biological make-up is like our world. Heidegger maintains that being-in-the-world is constitutive of Dasein independently of any empirical research; for the existential analysis of Dasein is concerned with what is constitutive of us qua Dasein in distinction to empirical research $(\S 10$, pp. 49-50; $\S 12$, pp. 57-58). We can therefore say that insofar as something is being minded, it is ontologically dependent on being embedded in a physical environment. (I shall use the terms "constitutive of" and "ontologically dependent on" interchangeably; another equivalent term would be "metaphysically dependent on").

The claim that the mind is not ontologically self-sufficient is important in arguing against a Cartesian philosophy of mind. However, at the centre of today's discussion is epistemological externalism. This is the claim that the content of our thoughts is ontologically dependent on the constitution of the physical world in which we are embedded. Heidegger's philosophy of Dasein includes not only ontological, but also epistemological externalism. Being-in-the- 
world implies for Heidegger not only being embodied, but also having already discovered the world:

[56] When Dasein directs itself towards something and grasps it, it does not somehow first get out of an inner sphere in which it has been proximally encapsulated, but its primary kind of Being is such that it is always 'outside' alongside entities which it encounters and which belong to a world already discovered. ( $\$ 13$, p. 62 ; see also $\S 12$, in particular p. 55)

Being-in-the-world thus includes being in an epistemic sense at the things that there are in the world ( $\$ 13$, pp. 59-61; $§ 18$, p. 87; $§ 43 a$, pp. 202-207). Hence, there can be no knowledge of any sort if there is no epistemic link to a non-human environment in the sense of thoughts that are about this environment - without any internal representations intervening as epistemic mediators between these thoughts and the world. ${ }^{11}$ The claim that qua minded beings we are in the world in the sense that the content of our thoughts is ontologically dependent on the constitution of the physical world is the idea that drives today's externalism. ${ }^{12}$

In order to reconstruct Heidegger's argument for epistemological externalism, we can further elaborate on the line of argument that runs from (1) existence as essence via (2) the relaton to oneself to (3) being-in-the-world. According to Heidegger, the relation to oneself is such that practical dealings with the environment come before its theoretical conceptualization in forming propositional thoughts about the environment. ${ }^{13}$ For the relation to oneself is not a theoretical one of contemplating a pre-determined essence, but a practical one of projecting oneself upon possibilities for one's existence and carrying out such possibilities. Since Dasein does not create itself, these possibilities require a physical environment in which they can be realized.

The argument for epistemological externalism thus is this one: Having thoughts with a propositional content presupposes practical dealings with the environment. This presupposition is not a contingent matter. It follows from what is constitutive of Dasein. Consequently, by presupposing practical dealings with the environment, the propositional thoughts of a person are ontologically dependent on the physical environment in which the person is embedded. This argument does not establish that the content of thoughts of particular types is ontologically dependent on specific features of the environment. However, it sets out to show that the content of our thoughts in general is ontologically dependent on the physical environment with which we deal. Let us take a closer look at this argument.

The claim that practical dealings with the environment have priority over its conceptualization in propositional thought is to say in Heidegger's terms that one copes with the environment as something ready-to-hand (Zuhandenes) before conceptualizing it as something being present-at-hand (Vorhandenes). It is something dealt with for practical purposes before properties are predicated of things. Coping with the environment as something ready-to-hand is a candidate for a feature that is characteristic of Dasein, because it is a purposive activity. Nonetheless, [57] insofar as it is a purposive activity, it presupposes a cognitive access to the environment. Heidegger acknowledges such a cognitive access in

11 See also the direct epistemic access to the world that Olafson proposes under the heading of "presence", building on Heidegger's conception (Olafson (1987), Chapter 2, and Olafson (1995)).

12 For an overview see McCulloch (1995), in particular Chapters 7 and 8.

13 In particular $\S 15$, pp. 67-72; § 16, p. 76; § 18, p. 85. See Dreyfus (1980) and Okrent (1988), in particular pp. 31-39, 130-155. 
dealing with the environment as something ready-to-hand. He speaks of a pre-predicative seeing; this seeing nevertheless is a seeing of something as something - without, however, being a seeing that something is the case:

In dealing with what is environmentally ready-to-hand by interpreting it circumspectively, we 'see' it as a table, a door, a carriage, or a bridge; but what we have thus interpreted [Ausgelegte] need not necessarily be also taken apart [auseinander zu legen] by making an assertion which defintely characterizes it. ( $\$ 32$, p. 149 ; see also $§ 15$, p. 67)

Thus, in dealing with things as something ready-to-hand, we have a cognitive access to things insofar as we classify them in our actions according to what we can do with them. This cognitive access is pre-predicative, because it is not conceptual. Something is treated as a table, a door, etc., but the concepts "table", "door", etc. are not used. Using concepts and thus predicating properties of something is a derivative mode of interpretation (Auslegung). According to Heidegger, the "as" of the assertion - predicating properties of something and thus treating it as something present-at-hand - originates in the "as" of an interpretation which understands circumspectively in treating things as something ready-to-hand ( $\$ 33$, pp. 157-158; compare $\S 13$, pp. 61-62; § 69b, pp. 359-361).

Consequently, it would be misleading to say that Heidegger's characterization of Dasein as care implies that practice comes before theory (compare $\S 41$, p. 193): practice comes before theory in the sense that practical dealings with the environment are primordial and its conceptualization in propositional thought is derivative. But a pre-predicative cognitive access to the environment is part and parcel of these practical dealings. If one counts this prepredicative cognitive access as belonging to the theoretical side of intentionality, then theory and practice are equiprimordial.

However, it can be objected that Heidegger does not make clear what is distinctive of Dasein in the cognitive access to the environment that is involved in dealing with things as something ready-to-hand. All what he says about that access can also be applied to the response-mechanisms that even primitive living beings apply in their reactions to their environment. Such response-mechanisms can be reliable and discriminatory. A snail, for instance, distinguishes in her behaviour between a wet and a dry environment in a reliable way. She classifies the environment as wet or dry and thereby apparently interprets (auslegen) it as wet or dry without employing the concepts "wet" or "dry". Why is this not a case of treating the environment as something ready-to-hand? ${ }^{14}$ Answering at this point that the snail does not project herself upon possibilities, but has a pre-determined function, etc., would be circular; for what is required is to reveal a [58] feature that is characteristic of Dasein in that pre-predicative, cognitive access to the environment.

Given his conception of Dasein in terms of the essence of Dasein being its existence, Heidegger has an argument for being-in-the-world that amounts to an ontological externalism. There is a thread visible how this argument can be extended in such a way that includes an epistemological externalism as well: the relationship of each token of Dasein to itself is such

14 Mulhall (1990), in particular Chapter 4, regards Heidegger's treatment of our access to things as something ready-to-hand in such a way that the sight which is involved in praxis without theory (p. 120) captures aspect perception. According to Mulhall, aspect perception "highlights what is distinctively human about human behaviour in relation to things in the world" (p. 1). However, as far as Heidegger is concerned, the question remains how the pre-conceptual access to the world that Heidegger assumes can be something distinctively human. 
that practical dealings with the environment precede its conceptualization in propositional thought. But Heidegger then fails to make clear what is distinctive of Dasein in the cognitive access to the environment that practical dealings involve. His argument falls short of the ontological necessity that is required to establish that intentional states with a propositional content presuppose in a constitutive way practical dealings with the world which belong themselves to the intentionality that is characteristic of Dasein.

Nonetheless, it is here that the discussion on externalism in today's analytic philosophy may come in. The argument for externalism on which this discussion focuses is not about practical dealings with the environment that are a prerequisite for propositional thought. This discussion tackles propositional thought directly. The arguments that have been developed since Putnam (1975) seek to establish that having thoughts with a particular content - such as thoughts that employ natural kind terms like "water" - is ontologically dependent on the nonhuman environment in which a thinking being is embedded. In distinction to Heidegger's position, today's arguments thus have a direct dependence of particular types of thought on the particular make-up of the environment in view. What Heidegger's being-in-the-world and today's externalism have in common is the idea of a direct epistemic access to the world in such a way that the content of our thoughts is ontologically dependent on the way the nonhuman environment is.

\section{Being-with and a social theory of intentionality}

Let us now consider how Heidegger's claim that Dasein is tied to Being-with relates to a social theory of intentionality. A social theory of intentionality is a sort of externalism too, namely a social externalism. According to such a theory, intentional states are neither ontologically nor epistemologically self-sufficient: insofar as something is a minded being and has intentional states with a determinate conceptual content, it is dependent on interacting with other such beings.

Again, we have to distinguish between a trivial and a substantial version of such a claim. The trivial version is that human beings live in fact in social communities, that children would not develop into adults that speak a language if they were deprived of social interactions, etc. These are claims about the contingent situation of us human beings. They establish a causal dependence that is contingent upon our biological equipment. Furthermore, claims about the division of linguistic labour (Putnam (1975)) are not trivial and not contingent upon our biological equipment. But these claims only show that given a linguistic community, speakers refer to experts when it comes to the meaning of terms in those fields in which they are not experts themselves. What has to be shown in order to establish a social theory of intentionality in a substantial philosophical sense is that it is constitutive of a minded being that there are other minded beings with [59] whom that being interacts. In other words, insofar as something is a minded being, it is ontologically dependent on interacting with other minded beings.

Heidegger's intention is to establish such a substantial claim: as mentioned in the last but one section, he claims that Being-with is part and parcel of being-in-the-world. However, when it comes to working out that claim - and working out in particular how the content of our thoughts is dependent on social interactions - Heidegger fails to establish an ontological dependence. When introducing Being-with in $\S 26$, he simply takes up interactions with other people as a phenomenon that is characteristic of our life (pp. 117-119). In treating things as 
something ready-to-hand, we encounter other persons. But then Heidegger claims to have thereby shown that Being-with is something that is constitutive of Dasein:15

The phenomenological assertion that "Dasein is essentially Being-with" has an existentialontological meaning. It does not seek to establish ontically that factically I am not present-athand alone, and that Others of my kind occur. If this were what is meant by the proposition that

Dasein's Being-in-the-world is essentially constituted by Being-with, then Being-with would not be an existential attribute which Dasein, of its own accord, has coming to it from its own kind of

Being. ( $\$ 26$, p. 120; see also pp. 123, 125)

However, since Heidegger fails to develop arguments for such an ontological dependence in distinction to the trivial, factual dependence, the result is the same as in the case of epistemological externalism: Heidegger's Being and Time does not supply us with arguments that are strong enough to establish the claim that the content of our thoughts is ontologically dependent on social interactions.

Nonetheless, this is again a point where Heidegger's conception of Dasein and today's analytic philosophy can complement each other: Heidegger's conception provides a framework for a view of ourselves. This framework leads to the claim that insofar as we are minded beings, we are ontologically dependent on interactions with other minded beings in a social community. Today's analytic philosophy may be in a position to supply detailed arguments for that claim.

\section{Conclusion}

Why does Heidegger not succeed in working out theses such as being-in-the-world qua externalism and Being-with qua a social theory of intentionality in such a way that these theses are vindicated as describing features that are constitutive of ourselves qua minded beings? In order to establish claims such as the one that for having thoughts it is constitutive (a) to be embedded in a non-human environment and (b) to interact with other persons, these claims have to be tested against counterfactual situations. That is to say, given a situation in which conditions such as being embedded in an appropriate environment and interacting with other persons are not fulfilled, it has to be shown why a being in such a counterfactual situation does not have thoughts. Heidegger's arguments are not conclusive, because they do not establish these claims in a counterfactually robust way.

[60] Recall the main argument in today's philosophy for meaning being dependent on the constitution of the physical environment in which a thinking being is embedded. Putnam (1975) sets out to show that the meaning of thoughts in which natural kind concepts, such as "water" or "tiger", are employed depends on the physical constitution of the things referred to. For instance, independently of whether or not people know that water is $\mathrm{H}_{2} \mathrm{O}$, it is part of the meaning of their thoughts about water that water is $\mathrm{H}_{2} \mathrm{O} .{ }^{16}$ Putnam's argument is built on a thought experiment that imagines a counterfactual situation: He conceives a situation in which the constitution of the environment is varied (twin-earth, where water is not $\mathrm{H}_{2} \mathrm{O}$ ). $\mathrm{He}$ then develops a detailed argument to show that in this situation the thoughts in question differ in meaning from our thoughts. Whatever reservations one may have about thoughtexperiments of that type - and the discussion that Putnam's thought-experiment triggered in

15 See also the criticism of Sartre (1976), p. 286, who speaks of an affirmation without foundation.

16 As regards relating Heidegger to today's externalism and Putnam in particular, see Lafont (1994), Chapter 4, especially p. 267. 
particular - some consideration of counterfactual situations is indispensable in order to distinguish claims about constitution and thus ontological dependence from contingent claims.

Turning to a social theory of intentionality, a prominent type of arguments for such a theory in today's philosophy is built on thought experiments that are similar to the famous one of Putnam (1975) (in particular Burge (1979)). However, Burge's arguments do not reach as far as showing that the thoughts of a person cannot have any determinate content at all apart from social interactions. As to an argument that seeks to establish that latter claim, we can turn to the rule-following considerations that Kripke (1982) attributes to Wittgenstein's Philosophical Investigations. Kripke's proposal is that insofar as meaning is determinate at all, it is determined by certain normative attitudes that we adopt to each other, thereby creating certain social practices. Consequently, having thoughts with a determinate conceptual content depends on being a member of a social community. Kripke (1982) does not proceed by means of a thought experiment like the one of Putnam (1975). Nonetheless, his argument also is counterfactually robust: he considers various possible situations (dispositions to behaviour, grasping Fregean senses, etc.) and shows why in these situations there is no determinate meaning.

One cannot compare Heidegger's arguments, based on a phenomenological method, in a straightforward way to these arguments in today's analytic philosophy. My point is: (a) These analytical arguments help us to understand why Heidegger does not succeed in establishing his epistemological claims in such a way that there is a clear distinction between contingent and constitutive dependencies. (b) We can use these arguments in order to strengthen the general systematic claims that Heidegger has in mind about our thoughts being dependent on the non-human as well as the social environment in a constitutive way.

To conclude, thus, on the one hand, what Heidegger's Being and Time can provide for analytic philosophy is a view of ourselves that shows in positive terms how a reification of ourselves qua minded beings can be avoided and how being minded does not add anything to the entities that there are in the world without its description being reducible to a naturalistic description. On the other hand, the arguments for externalism and a social theory of intentionality in today's [61] philosophy can supply in analytic clarity the details for working out one form that such an account of ourselves can take. This, I claim, is a point where Heidegger's Being and Time and today's analytical philosophy can meet in a way that is profitable for both sides.

$C V$ : Michael Esfeld is Privatedocent and Heisenberg Fellow at the University of Konstanz, Germany, and Lecturer in Philosophy at the University of Hertfordshire, England. His main research areas are the philosophy of mind and language, epistemology, and the philosophy of science. Publications include a book on Holism in Philosophy of Mind and Philosophy of Physics, forthcoming with Kluwer, Synthese Library, "Physicalism and Ontological Holism" in Metaphilosophy 30 (1999), pp. 319-337, and "Holism and Analytic Philosophy" in Mind 107 (1998), pp. 365-380.

E-mail address: Michael.Esfeld@ uni-konstanz.de 


\section{References}

Brandom, Robert B. (1983): “Heidegger's Categories in Being and Time”. Monist 66, pp. 387-409. Reprinted in Hubert L. Dreyfus and Harrison Hall (eds.): Heidegger: A Critical Reader, Oxford: Blackwell 1992, pp. 45-64.

Brandom, Robert B. (1994): Making It Explicit. Reasoning, Representing, and Discursive Commitment. Cambridge (Massachusetts): Harvard University Press.

Burge, Tyler (1979): "Individualism and the Mental”. In: P. A. French, T. E. Uehling \& H. K. Wettstein (eds.): Studies in Metaphysics. Midwest Studies in Philosophy. Volume 4. Minneapolis: University of Minnesota Press. Pp. 73-121.

Christensen, Carleton B. (1997): “Heidegger's Representationalism”. Review of Metaphysics 51, pp. 77-103.

Christensen, Carleton B. (1998): "Getting Heidegger Off the West Coast". Inquiry 41, pp. 65-87.

Dretske, Fred I. (1995): Naturalizing the Mind. Cambridge (Massachusetts): MIT Press.

Dreyfus, Hubert L. (1980): "Holism and Hermeneutics". Review of Metaphysics 34, pp. 3-23.

Dreyfus, Hubert L. (1991): Being-in-the-World. A Commentary on Heidegger's “Being and Time”, Division I. Cambridge (Massachusetts): MIT Press.

Gethmann, Carl Friedrich (1993): Dasein: Erkennen und Handeln. Heidegger im phänomenologischen Kontext. Berlin: de Gruyter.

Haugeland, John (1982): "Heidegger on Being a Person”. Noûs 16, pp. 15-28.

Haugeland, John (1989): “Dasein's Disclosedness”. Southern Journal of Philosophy. Supplementary Volume 28, pp. 51-73.

Haugeland, John (1998): Having Thought. Essays in the Metaphysics of Mind. Cambridge (Massachusetts): Harvard University Press.

Heidegger, Martin (1947): Platons Lehre von der Wahrheit. Mit einem Brief über den «Humanismus». Bern: Francke.

Heidegger, Martin (1962): Being and Time. Translated by John Macquarrie and Edward Robinson. London: SCM Press.

Heidegger, Martin (1993): Sein und Zeit. Tübingen: Niemeyer. 17th edition. First published in Jahrbuch für Philosophie und phänomenologische Forschung 8 (1927), pp. 1-438, and separately Halle 1927.

Kripke, Saul A. (1982): Wittgenstein on Rules and Private Language. Oxford: Blackwell.

Lafont, Cristina (1994): Sprache und Welterschliessung. Zur linguistischen Wende der Hermeneutik Heideggers. Frankfurt (Main): Suhrkamp.

McCulloch, Gregory (1995): The Mind and its World, London: Routledge.

McDonough, Richard M. (1995): "Heidegger, Externalism, and Mechanism”. Journal of the British Society for Phenomenology 26, pp. 127-146.

McDowell, John (1994): Mind and World. Cambridge (Massachusetts): Harvard University Press.

McManus, Denis (1999): “The Rediscovery of Heidegger's Worldly Subject by Analytic Philosophy of Science". Monist 82, pp. 324-346.

[62] Mulhall, Stephen (1990): On Being in the World. Wittgenstein and Heidegger on Seeing Aspects. London: Routledge.

Okrent, Mark (1988): Heideggers's Pragmatism. Understanding, Being, and the Critique of Metaphysics. Ithaca: Cornell University Press.

Olafson, Frederick A. (1987): Heidegger and the Philosophy of Mind. New Haven: Yale University Press.

Olafson, Frederick A. (1995): What is a Human Being? A Heideggerian View. Cambridge: Cambridge University Press.

Ortega, Mariana (2000): “Dasein Comes after the Epistemic Subject: But Who Is Dasein?”. International Philosophical Quarterly 40, pp. 51-67.

Pettit, Philip (1993): The Common Mind. An Essay on Psychology, Society, and Politics. Oxford: Oxford University Press. 
Philipse, Herman (1998): Heidegger's Philosophy of Being: A Critical Interpretation. Princeton: Princeton University Press.

Putnam, Hilary (1975): “The Meaning of 'Meaning””. In: H. Putnam (ed.): Mind, Language and Reality. Philosophical Papers Volume 2. Cambridge: Cambridge University Press. Pp. 215-271.

Quine, Willard Van Orman (1960): Word and Object. Cambridge (Massachusetts): MIT Press.

Sartre, Jean-Paul (1956): Being and Nothingness. An Essay in Phenomenological Ontology. Translated by Hazel E. Barnes. New York: Philosophical Library.

Sartre, Jean-Paul (1976): L'être et le néant. Essai d'ontologie phénomenologique. Paris: Gallimard. First published 1943.

Sartre, Jean-Paul (1996): L'existentialisme est un humanisme. Paris: Gallimard. First published 1946. 